\title{
EXAMPLES OF SHOCKS IN POPULATION DYNAMICS
}

\author{
Elina Dévoué AND Victor Dévoué
}

Abstract. The aim of this paper is to study some shocks in population dynamics by means of the recent theories of generalized functions in order to have a better understanding of the long-term behavior of these phenomena. The shocks analyzed can be wars, genocides, epidemics, natural disasters, cancers... Population dynamics is represented by the transport equation and shocks by initial data which are distributions. This justifies to search for solutions in Colombeau algebra. Moreover we build well-posed problems. We study two models, the genesis model and a top hat condition.

Mathematics subject classification (2010): 35D99, 35L05, 35L70, 46F30.

Keywords and phrases: Colombeau algebra, generalized functions, transport equation, nonlinear partial differential equations, population dynamics, shocks.

\section{REFERENCES}

[1] J. Aragona, Colombeau generalized functions on quasi-regular sets, Publicationes Mathematicae Debrecen, 68, 3-4 (2006), 371-399.

[2] J. Aragona, A. R. G. Garcia And S. O. JuriaAns, Generalized solutions of a nonlinear parabolic equation with generalized functions as initial data, Nonlinear Analysis, 71 (2009), $5187-$ 5207.

[3] Banque Mondiale, L'IDA en action. Gérer les risques naturels, réduire les risques liés au développement, Washington D. C., 2008.

[4] J. R. Barnett And M. Webber, Accomodating Migration to Promote Adaptation to Climate Change, World Bank Policy Research, Working Paper 5270, 2010.

[5] H. A. Biagioni, A nonlinear theory of Generalized Functions, Lecture Notes in Mathematics 1421, Springer-Verlag, 1990.

[6] E. Canales, 1808-1814: Démographie et guerre en Espagne, Annales historiques de la Révolution française, 336 (2004), 37-52.

[7] S. J. Chapman, M. J. Plank, A. James and A. B. Basse, A nonlinear model of age sizestructured populations with applications to cell cycles, The ANZIAM Journal 49, 2 (2007), 151-169.

[8] P. Collier, On the economic consequences of Civil War, Oxford Economic Papers, 51 (1999), 168183.

[9] J. F. Colombeau, New Generalized Functions and Multiplication of Distributions, North Holland, Amsterdam, Oxford, New-York, 1984.

[10] J. F. ColombeaU, Elementary introduction to new generalized functions, North Holland Mathematics Studies 113, North-Holland, Amsterdam, 1984.

[11] J. M. Cushing And J. Li, Juvenile versus adult competition, Journal of Mathematical Biology 29 (1991), 457-473.

[12] A. Delcroix, Remarks on the embedding of spaces of distributions into spaces of Colombeau generalized functions, Novi Sad Journal of Mathematics, 35, 2 (2005), 27-40.

[13] A. Delcroix, V. DÉvoué And J.-A. Marti, Generalized solutions of singular differential problems. Relationship with classical solutions, Journal of Mathematical Analysis and Applications 353, 1 (2009), 386-402. 
[14] A. Delcroix, V. DÉvouÉ And J.-A. MarTi, Well posed problems in algebras of generalized function, Applicable Analysis, 90, 11 (2011), 1747-1761.

[15] R. DilaO AND A. LAKMECHE, On the weak solutions of the McKendrick equation: Existence of demography cycles, Mathematical Modeling of Natural Phenomena, 1, 1 (2006), 1-32.

[16] M Iannelli, Mathematical Theory of Age-Structured Population Dynamics, Giardini Editori e stampatori in Pisa 1995.

[17] M. D. Johnston, C. M. Edwards, W. F. Bodmer, P. K. Maini and S. J. Chapman, Mathematical modeling of cell population dynamics in the colonic crypt and in colorectal cancer, Proceedings of the National Academy of Sciences of the United States of America, 104, 10 (2007), 4008-4013.

[18] I. KMIT, A distributional solution to a hyperbolic problem arising in population dynamics, Electronic Journal of Differential Equations, 132 (2007), 1-23.

[19] J. A. LotKA, Théorie analytique des associations biologiques, Hermann, Paris, 1934 and 1939.

[20] J.-A. MARTI, Fundamental structures and asymptotic microlocalization in sheaves of generalized functions, Integral Transforms and Special Functions 6, 1-4 (1998), 223-228.

[21] J.-A. MARTI, $(\mathscr{C}, \mathscr{E}, \mathscr{P})$-Sheaf structure and applications, Nonlinear theory of generalized functions (eds M. Grosser and al.), Research Notes in Mathematics, Chapman \& Hall/CRC (1999), 175-186.

[22] J.-A. MARTI, Non linear Algebraic analysis of delta shock wave to Burgers' equation, Pacific Journal of Mathematics, 210, 1 (2003), 165-187.

[23] A. G. McKendrick, Applications of Mathematics to Medical Problems, Proceedings of the Edinburgh Mathematical Society, 44 (1926), 98-130.

[24] NORHAYATI AND G. C. WAKE, The solution and stability of a nonlinear age-structured population model, The ANZIAM Journal, 45 (2003), 153-165.

[25] ORganis ATION DE L'Unité AfRiCAine, Rapport sur le génocide du Rwanda. Le génocide qu'on aurait pu stopper, Nations Unies 2000.

[26] B. Perthame, S. Mischler, J. Clairambault and B. Laroche, A mathematical model of the cell cycle and its control, Rapport de recherche 4892, Institut National de Recherche en Informatique et en Automatique, 2007.

[27] L. Schwartz, Théorie des Distributions, Hermann, Paris, 1966.

[28] D. Schweisguth, Japon: Séisme et tsunami, quel impact sur la croissance?, Publications de l'OCFCE, Centre de recherche en économie de Sciences Politiques 2011.

[29] M. Verpoorten And L. Berlage, Economic Mobility in Rural Rwanda: A Study of the Effects of War and Genocide at the Household Level, Journal of African Economies, 3 (2007), 349-392. 